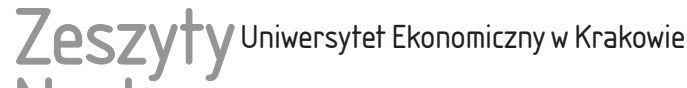 Naukowe
}

9(969)

ISSN 1898-6447

Zesz. Nauk. UEK, 2017; 9 (969): 69-80

DOI: 10.15678/ZNUEK.2017.0969.0905

Katarzyna Świetla

\section{Locating Accounting Outsourcing Centres in the Countries of Central and Eastern Europe in the Light of Global Conditions - Research Proposal}

\begin{abstract}
The aim of this study is to present what makes the location of accounting outsourcing centres successful given the complexity of their operations. For this purpose, a matrix developed by the author will be used (established on the basis of a pilot study realised in 2016) on the relationship between the complexity of processes and the costs generated in connection with their implementation. The study is currently being prepared (including an analysis of outsourcing market investors, decision-making in the proper sampling, and refining the specific research questions) and its planned execution time is 2017/2018. At this stage, basic research questions and hypotheses were formulated, and a preliminary selection of the statistical method permitting assessment of the studied parameters was made. The study's results are to be made available to the parties concerned as a tool to support decision-making regarding the location of centres of outsourcing of accounting in the countries of Central and Eastern Europe.
\end{abstract}

Keywords: outsourcing, costs, benefits, delegated processes, business location. JEL Classification: M41, I25.

Katarzyna Świetla, Cracow University of Economics, Faculty of Finance and Law, Department of Financial Accounting, Rakowicka 27, 31-510 Kraków, e-mail: katarzyna.swietla@uek. krakow.pl 


\section{Introduction}

In today's world of modern economy and finance, overcoming barriers to business development requires expert knowledge and commitment. The range of information needed to effectively manage companies increasingly exceeds the competence of persons employed in economic entities, making it necessary to use outside specialised services. Additionally, awareness is rising among users of outsourcing, who see this process as an opportunity not only to reduce costs, but most of all, to leverage the synergy available when expertise, practices, and access to the latest technologies that have a significant impact on achieving a competitive position on the market are combined.

In the financial sphere, the growing information needs bring about new demands made by entrepreneurs. This, in turn, results in increased interest in corporate accounting services. Against this background, the outsourcing of finance and accounting, which have grown so quickly thanks to the maturity and stability of the processes offered, should be pointed out in particular. Central, Eastern and South Europe is well-established as a world-class destination for Shared Services Centres and Business Process Offshoring investment. Alongside Poland and its leading location in the region, other countries such as Romania, Czech Republic and the Baltic countries are important investment destinations, and have become leading global locations for key business services. According to data from 2016, more than 1,100 service centres with foreign capital, hailing mostly from the US and the developed countries of Western Europe, operate in the area.

According to data for the first quarter of 2016, in Poland alone, there were 676 foreign centres (461 investors) and employment in them stood at 177,000 (ABSL 2016), which indicates the magnitude of the "pie" feeding the economies of individual countries.

The aim of the study is to present studies, to be done by the author in 2017/2018, on the global determinants of the location of accounting outsourcing centres in the countries of Central and Eastern Europe (CEE). The key objective is to predict the distribution of outsourcing centres so that determining an optimal use of resources (human, technological, etc.) offered by a specific country (region) benefits the parties involved to the greatest extent. It will be implemented in the context of global locations of accounting outsourcing centres in Central and Eastern Europe (CEE).

The research analyses and evaluates key determinants of optimising resources for the needs of outsourcing centres and their customers. Against this background, recommendations are made so that management decisions in this area could be streamlined. 
With the research in the pilot stage, the article presents the preliminary assumptions, which are the starting point for predicting the location of outsourcing centres, and which will be verified at the stage of practical implementation of the study.

\section{An Overview of International Research in the Field of Outsourcing Centre Locations in Europe}

Research on the importance and role of outsourcing in the global economy has been carried out in the international arena for many years. At the same time, accounting outsourcing should be seen as an ongoing comprehensive process rather than outsourcing of a single independent service (Blokdijk 2008). For the most part, the research concerns the basis for making decisions on the use of external service entities, the rules governing the provision of service and the possible risks. Such studies were covered by the literature review done by T. Kremic, O. Icmeli and W. O. Rom (2006). The authors based their discussion on the analysis of 200 sources and classified the types of studies conducted therein, pointing out key features. In another paper, B. Orliński (2013, pp. 229-240) highlighted issues at work in the global market's competitiveness on the basis of outsourcing and draws attention to the consequent cost reduction, increased operating margins and better productivity. In recent years, extensive research has also been carried out to compare outsourcing in the US and European economies. Thorough, long-term research in this area was done by M. Lacity and R. Hirschheim (1995) and, cooperating with them, L. Willcoks and G. Fitzgerald (1995, pp. 333-351), who focused on practical tasks in the outsourcing of information systems (also commonly used to handle accounting processes) and indicating the sometimes different understanding of expectations by providers and recipients of services and improper practices in the implementation of tasks. A. Kakabadse and N. Kakabadse (2002, pp. 189-198) did their work in a similar context, concluding that American companies used the strategies available to them to achieve the greatest added value, while the European ones expected to obtain economies of scale.

In their discussion of the role of transnational outsourcing and its impact on the internal and global convergence of solutions, Egger and Pfaffermayr (2004, pp. 833-843) also examine outsourcing. The internationalisation of economic activities including trade, production and investment increasingly often involves the transfer of research and development, on top of services to developing countries (including the transition countries of Central-Eastern Europe). According to this trend, developing countries and those subject to a transformation have enormous potential to attract investments, a fact numerous scientific studies have 
confirmed. This is a result of the growing importance of these locations for business service centres in recent years. The new division of the outsourcing "pie" and its shift in the direction of Eastern Europe drew the attention of D. Marin, who analysed the German and Austrian investments. She also pointed to the question of cost, tax and organisation associated with decision-making (Marin 2006, pp. 612-622). The transfer of selected processes to Eastern Europe has also been studied by I. Geishecker (2006, pp. 559-583) in the context of the demand for labour in German industry.

The increasing role of outsourcing is also the result of the ICT revolution, which enables transport services abroad and involves them in international trade, affecting the development of this sector (Szymaniak \& Pniewski 2008, p. 7) thanks to the growth of merchantability services (Masłowski 2005, p. 19). It also allows companies to be downsized appreciably, a badly needed measure in the recent years of the economic crisis.

The global spread of process delegation has mostly occurred in the services industry, though the issues concerning the transfer of selected activities to other regions and countries, according to the review of the literature, has been discussed and analysed for years, regardless of what processes they relate to.

In this article I focus on the location of service centres for accounting processes. This is a result of the approach to information coming from the accounting system, which is primarily affected, in advanced economies, by the presence of trained specialists who not only collect and store data, but also present and analyse them on many levels (Gelinas and Dull 2009, p. 26).

As it is increasingly claimed, information provided by accounting is a kind of product that should meet specific expectations (Micherda 2006, p. 11), so accounting services have been developed. The scope, form and quality of their implementation depend, in large measure, on the choice of places to locate the outsourcing centre (usually assessed based on knowledge, competencies and skills of the local workforce, but also their communications capabilities and availability of office space, which will affect the costs generated).

\section{The Preparatory Phase of the Research}

Among the most important issues which one needs to consider at the stage of preparing the research is the right formulation of the research problem and posing some questions that define the expectations for the realisation of the objective.

The research problem: To analyse the key determinants affecting the location of accounting service centres in the context of outsourcing accounting services in selected countries. The study will examine the global circumstances that have 
a significant impact on the location of outsourcing centres in specific countries and against the background of past experiences. The study will also attempt to determine how and when service packages are passed from an outsourcers to an outsourcee in the new country, which requires the latter to handle the former in a more sophisticated way, using appropriate databases.

Basic research questions:

1. Which factors are most important for investors looking for the best locations for their outsourcing centres in specific countries and regions?

2. How do investors determine which tasks are to be carried out by individual centres?

3. What has affected the changes taking place in the services performed?

Aim of the study: The study aims to predict the distribution of outsourcing centres in order to determine the optimal use of resources (human, technological, etc.) offered by specific countries (or regions) in ways that optimise the benefits for the parties involved.

Carrying out the project in practice should serve to determine where a given outsourcing company should set up its branches in a particular country or region. It could also clarify the levels of technological advancement that can be expected from target outsourcing markets according to the level of their advancement and encourage their further evolution.

Accounting is increasingly regarded as a comprehensive process aimed at growing the dynamics and effectiveness of the entity and achieving better financial performance through access to knowledge and precision tools provided by the service provider (Felton 2008, Gronroos 2007). Moreover, investors in the outsourcing industry need access to skilled candidates to do the work and a location. Knowledge of foreign languages and high industry competence are of the utmost importance, while an advantageous location is one with a less developed infrastructure and employment that is not too low.

For the study, I will expand and refine this range of factors.

\section{Research Methodology}

The methods adopted for the study include a critical analysis of the literature and legal solutions in power that affect outsourcing; an analysis of up-to-date experiences regarding factors that determine the location of outsourcing centres in selected regions; an analysis of internal documentation of the selected entities with a particular focus on the costs incurred; interviews with decision-makers concerning the location of the centres; and Tau Kendall correlation analysis. 
Research fundamentals: The key to the success of the study is to thoroughly select the methods and the entities to be researched, as is the expected feedback about the results that would make it possible to raise the efficiency of the entities' activities (in this case, the right choice for the site location of planned outsourcing centres in the context of the tasks to be carried out and competences). To this end, the hypotheses will be verified based on the research questions specified in Section 1, which will be developed with 4 to 5 detailed points.

Form of the study: This study will begin its preliminary phase based on a critical analysis of the available literature and reports of international research companies operating in the outsourcing sector worldwide, with a particular emphasis on the CEE region. The next stage will analyse factors contributing to the existing locations of outsourcing centres in the years 2005-2015. It will also provide a detailed identification, verification and evaluation of activities carried out in the centres within the chosen period. For this purpose, internal documentation of individual units and interviews with members of their boards will be used.

Regional factors to be considered:

- the size of the accounting market (2015 Top 100... 2015),

- the development and stability of the accounting services market (Nadolna 2007; Sektor nowoczesnych... 2015),

- competition in the market for accounting services expressed by punctuality and prices (Zarzycka \& Michalak 2013, p. 183),

- knowledge, practice and ethical standards presented by the accounting services providers (Business Services... 2015),

- providers' tendency to pursue continuous education (skills development),

- the flexibility of accounting service offers and the tendency among outsourcing partners to consistently increase the quality of cooperation (Davis 2006).

The ultimate group of factors to be considered will be wider once the practical implementation of the study has begun.

There are also strict quality requirements for the given tasks, in the form of norms and standards. The size of the processes and requirements of certificates and diplomas are likewise important, as is the final decision regarding the factors underlying the choice of a partner, the location of branches, and the area of assigned operations being preceded by an analysis of factors affecting the efficiency and effectiveness of the services provided. A failure to carry out such an analysis may cause client expectations not to be met and a misguided decision to be taken - that is, to separate an extremely important process such as accounting to an external entity (Świetla 2014; Zieliński 2008, p. 199). 
The effect of these actions should be to identify correct locations for outsourcing centres in the coming years.

Recipients of the study's results: The recipients of the conclusions drawn from the research will include companies locating their branches as well as specific local authorities, who may see cooperation as a means to developing their regions and having an impact on education and labour markets waiting to evolve. This rests on a positive assessment being conducive to employment growth in the outsourcing sector and the development of the market in which operations are carried out.

The conclusions are also to be published for a wider range of stakeholders to use. Hypotheses:

1. Factors that underpin the locations of outsourcing centres in a particular country or region are determined by the individual needs of the investor.

2. The advancement of packages of measures passed to implement within the branch office outsourcing companies in the region depends on the degree of economic development, education and technology in the region and its location.

3 . The tasks entrusted to specific countries or regions are subject to changes resulting from the evolution of knowledge, experience and the competences of the staff employed.

\section{Assumptions Underlying the Practical Implementation of the Proposed Research}

The studies' hypotheses will be verified based on the responses to the research questions.

Empirical verification of the hypotheses: The hypotheses will be verified using a task execution matrix elaborated in relation to their degree of complexity and cost of implementation. The study will analyse entities' expectations in locating a branch in Central or Eastern Europe and their subsequent implementation.

At the initial stage, I conducted a pilot study (interviews) among board members of 12 international centres. I selected centres represented in at least four different countries of Central and Eastern Europe, to be able to compare the determinants that were the most important for the location of a new centre. Answers to the questions about the reasons for the specific location of a centre were not confidential. Of the 15 interviewees, as many as 12 responded. Also, the type and scope of services are not a secret as they are part of the commercial offer directed at current and potential customers. 


\section{The Process Transformation Matrix}

Preliminary research has given rise to a matrix assigning tasks to specific locations described within the countries and cities below on the basis of costs incurred and their relation to the complexity of the processes to be outsourced.

At a later stage, an extensive research sample will be selected in order to be able to extrapolate the results to the entire community of outsourcers. On the basis of the study, the benefits and drawbacks of choosing a specific location for the execution of the tasks set out by investors will be presented. The key will assign locations (specific countries, regions or cities) to areas that meet specific conditions (including identification of the delegated tasks) - Table 1 .

Table 1. Relationship between the Cost of the Service and Specialisation

\begin{tabular}{|c|c|c|}
\hline Number & The Cost of Implementing Tasks & $\begin{array}{c}\text { How Advanced the Tasks } \\
\text { to Be Implemented Are }\end{array}$ \\
\hline 1 & Low & Low \\
\hline 2 & Low & Average \\
\hline 3 & Average & Low \\
\hline 4 & Average & Average \\
\hline 5 & Average & High \\
\hline 6 & High & Average \\
\hline 7 & High & High \\
\hline
\end{tabular}

Source: based on the author's own research.

The table indicates the relationships that can occur between the cost of the service and its specialisation. Usually, low cost is associated with the least specialised jobs that do not require highly skilled personnel (line 1). The cost grows with more elaborate accounting procedures that require more expert knowledge. Thus, the most complex tasks are the most costly (line 7). The situation indicated in line 2 indicates that semi-expert tasks associated with low cost should be assessed positively, and line 5 shows that average costs are connected with high competences. Positions 3 and 6 , where the costs are disproportionate to the expected results, show the opposite to be true. In such a case it would be advisable to reduce costs or raise staff qualifications in order to implement more advanced procedures.

The table does not present a situation where one can carry out more advanced tasks at a low cost and where uncomplicated tasks will be performed at a high cost. Based on previous research, I argue that such situations do not occur: The first case is not possible due to the level of staff education and technologies used, while the other is simply based on an irrational assumption. Both situations are therefore not considered. 


\section{A Correlation Analysis of the Results}

In order to verify the dependencies, correlation analysis will be used.

For this purpose, Kendall's Tau index will be employed. This index measures the strength of correlation between two traits. Statistics calculated using Kendall's Tau correlation will determine whether there is a relationship between two variables (the amount of costs and the advancement of the tasks to be performed).

The coefficient will be calculated using the following formula:

$$
\begin{gathered}
\tau=\frac{2\left(n_{C}-n_{D}\right)}{\sqrt{n(n-1)-T_{x}} \sqrt{n(n-1)+T_{Y}}} \\
T_{x}=\sum_{i=1}^{s}\left(t_{i x}^{2}-t_{i x}\right), \quad T_{Y}=\sum_{i=1}^{s}\left(t_{i y}^{2}-t_{i y}\right),
\end{gathered}
$$

where:

$n_{C}$ - the number of pairs of observations for which rank values for the characteristic $x$ and characteristic $Y$ vary in the same direction (the number of compatible pairs),

$n_{D}$ - the number of pairs of observations for which rank values for the characteristic $x$ and characteristic $Y$ vary in a different direction (the number of incompatible pairs),

$t$ - the number of cases included in the tied rank,

$\tau=1$ means the rank order is strongly "compatible" (monotonic increasing dependence), i.e. the growth of the independent variable corresponds to the increase in the dependent variable.

$\tau=-1$ means the rank order is strongly "incompatible" (monotonic decreasing dependence), i.e. the growth of the independent variable corresponds to the decrease in the dependent variable.

The result of the study should designate an area where it is possible to implement the most advanced services at the lowest cost incurred.

\section{Conclusion}

Service sector development is both an important indicator to measure the manifestations of globalisation and, frequently, the essence of a business' competitive advantages. Employment in this sector has risen consistently.

The research I have done to date has focused on the micro level, i.e. the market for domestic service providers in accounting, which were accounting offices in the region of Lesser Poland and their customers (Świetla 2014). Research on a transnational scope will identify potential reasons for the location of outsourcing centres 
in Central and Eastern Europe, including Poland, with a particular emphasis on its regions.

The study is intended to help outsourcing companies streamline decision-making concerning where to locate their branches. It is also meant to indicate how a region could be developed to make it an attractive place for locating a centre (there are many Polish cities where outsourcing is growing rapidly, including Krakow, Wroclaw, Warsaw, and the Tri-City, though other locations have gone unnoticed by investors).

Thus, it will be possible to "tailor" long-term cooperation that meets the expectations of all parties. This is important as outsourcing of accounting differs from many other services that are conducive to long-term contracts.

I have undertaken to provide such a basis for deciding on the location of outsourcing centres that will facilitate their use for the implementation of accounting and finance management processes in an optimal way in the CEE. If the solutions proposed herein are implemented, the services offered on the market should be matched with the possibilities of their realisation at the level expected in order to satisfy customer needs. The theoretical model to be constructed should therefore be translated into economic practice.

The importance of increased sourcing of organised service packages in the global economy is an economic trend and a requirement for the modern world. It is gaining particular importance in the still developing countries of Central and Eastern Europe. The role of Poland and other representatives of the region in the international arena of the business services industry is continuing to grow as individual cities become world leaders.

As follows from the above, rapid transformation of the services sector is the result of a process known as "servicisation", which has a significant impact on the growth of the role of new services in the economy, growth which has been brought about by their international exchange as a response to the potential of external demand.

\section{Bibliography}

2015 Top 100 Outsourcing Destinations, www.tholons.com (accessed: 18.12.2016).

Blokdijk G. (2008), Outsourcing 100 Success Secrets, 100 Most Asked Questions: The Missing IT, Business Process, Call Center,HR-Outsourcing to India, China and more Guide, G. Blokdijk, USA.

Business Services in Central 7 Eastern Europe (2015), www.absl.pl, http://ksiegowosc. infor.pl/raport-dnia/143827,Nowoczesne-technologie-IT-w-sluzbie-ksiegowego. html\#ixzz2wxxL0vrD, http://www.oecd.org/science/innovationinsciencetechnologya ndindustry/2101733.p (accessed: 20.02.2017). 
Davis D. (2006), Use of Service Credits to Mediate Performance in an Outsourcing Agreement (in:) P. Barr, R. Garvais (eds), Global Outsourcing Strategies: An International Reference on Effective Outsourcing Relationships, Gover Publishing Company, USA.

Egger P., Pfaffermayr M. (2004), Two Dimensions of Convergence: National and International Wage Adjustment Effects of Cross-border Outsourcing in Europe, "Review of International Economics", vol. 12, no 5, https://doi.org/10.1111/j.14679396.2004.00484.x.

Felton J. A. (2008), The Art of Outsourcing Information Technology, Author House, USA.

Geishecker I. (2006), Does Outsourcing to Central and Eastern Europe Really Threaten Manual Workers' Jobs in Germany?, “The World Economy”, vol. 29, no 5.

Gelinas U. J., Dull R. B. (2009), Accounting Information Systems, 8th ed., South-Western, USA.

Gronroos Ch. (2007), Service Management and Marketing, Customer Management in Service Competition, John Wiley \& Sons.

Kakabadse A., Kakabadse N. (2002), Trends in Outsourcing: Contrasting the US and Europe, "European Management Journal", vol. 20(2), https://doi.org/10.1016/s02632373(02)00029-4.

Kremic T., Icmeli O., Rom W. O. (2006), Outsourcing Decision Support: A Survey of Benefits, Risks and Decision Factors, Supply Chain Management, "An International Journal”, vol. 11, no 6, https://doi.org/10.1108/13598540610703864.

Lacity M. C., Hirschheim R. (1995), Information Systems Outsourcing: Myths, Metaphors and Realities, John Wiley \& Sons Inc., USA.

Marin D. (2006), A New International Division of Labor in Europe: Outsourcing and Offshoring to Eastern Europe, "Journal of the European Economic Association", vol. 4, nos 2-3, https://doi.org/10.1162/jeea.2006.4.2-3.612.

Masłowski A. (2005), Nowe formy usług opartych na wiedzy, "Handel Wewnętrzny", no 3.

Micherda B. (2006), Problemy wiarygodności sprawozdania finansowego, Difin, Warszawa.

Nadolna B. (2007), Outsourcing (in:) K. Czubakowska (ed.), Od auditingu do sponsoringu w rachunkowości, PWE, Warszawa.

Orliński B. (2013), Wpływ outsourcingu i offshoringu na konkurencyjność przedsiębiorstw w warunkach globalizacji, "Zarządzanie i Finanse”, vol. 1, no 2.

Sektor nowoczesnych usług biznesowych w Polsce (2015), www.absl.pl (accessed: 20.02.2017).

Sektor nowoczesnych ustug biznesowych w Polsce (2016), www.absl.pl (accessed: 20.02.2017).

Świetla K. (2014), Outsourcing usług księgowych w świetle oczekiwań biur rachunkowych i ich klientów, Wydawnictwo Uniwersytetu Ekonomicznego w Krakowie, Kraków.

Szymaniak A., Pniewski K. (2008), Globalizacja usług. Outsourcing, offshoring and shared services center, Wydawnictwa Akademickie i Profesjonalne, Warszawa.

Willcocks L., Lacity M., Fitzgerald G. (1995), Information Technology Outsourcing in Europe and the USA: Assesment Issues, "International Journal of Information Management”, vol. 15(5), https://doi.org/10.1016/0268-4012(95)00035-6.

Zarzycka E., Michalak M. (2013), Centra usług wspólnych (SSC) jako forma organizacji procesów rachunkowości - wyzwania dla praktyki i badań naukowych, "Studia i Prace Kolegium Zarządzania i Finansów”, no 130. 
Zieliński J. A. (2008), Outsourcing doradztwa podatkowego i rachunkowości w matej firmie, Wolters Kluwer, Warszawa.

\section{Globalne uwarunkowania lokalizacji centrów outsourcingu rachunkowości w krajach Europy Centralnej i Wschodniej - projekt badań} (Streszczenie)

Celem artykułu jest prezentacja przygotowywanego przez autorkę badania ukierunkowanego na uzasadnienie podstaw prawidłowej lokalizacji centrów outsourcingu rachunkowości w kontekście złożoności delegowanych do nich procesów. W tym celu wykorzystano opracowaną przez autorkę macierz (powstałą na podstawie zrealizowanego w $2016 \mathrm{r}$. badania pilotażowego) zależności pomiędzy złożonością procesów a kosztami ich realizacji. Badanie jest na etapie przygotowania (m.in. analizy rynku inwestorów outsourcingowych, podejmowania decyzji dotyczącej prawidłowego doboru próby, dopracowywania szczegółowych pytań badawczych), a jego zaplanowany czas realizacji to przełom lat 2017 i 2018. Na obecnym etapie wyznaczono podstawowe pytania badawcze, hipotezy oraz dokonano wstępnego wyboru metody statystycznej sprzyjającej ocenie badanych parametrów. Wyniki badania mają zostać udostępnione zainteresowanym stronom jako narzędzie wspierające podejmowanie decyzji dotyczących lokacji centrów outsourcingu rachunkowości w krajach Europy Środkowej i Wschodniej.

Słowa kluczowe: outsourcing, koszty, korzyści, delegowane procesy, lokalizacja działalności. 